\title{
The Heterarchic Structure of Twenty-First-Century International Governance
}

\author{
Jack Donnelly
}

\begin{abstract}
International governance is a feature of all international systems. Most acts of the changing forms of twenty-first-century international governance, however, present "global governance" as either sui generis or in terms of a historical comparison to the modern states system or medieval Europe. I characterize contemporary international governance instead in terms of a comparative analytical framework of general applicability based on a reconceptualization of the nature of international political structures. After some conceptual and analytical preliminaries, I sketch two models of special relevance: states systems (understood as systems of multiple relatively homogeneous territorial polities with relatively simple patterns of stratification) and "heterarchies" (systems of multiple functionally differentiated non-territorial centers arranged in divided or tangled hierarchies). Contemporary international society, I argue, can best be modeled as a states system with a heavy heterarchic overlay - and may be moving towards a heterarchic international system with a heavy states-system residue. After sketching this account, and illustrating it with the case of the governance of international human rights, I compare my framing with several leading alternatives, including global governance, multilevel governance, "fragmegration," neo-medievalism, and the embedded state. It is only the start to the story to say that the overwhelming predominance of strong and robust multifunctional states exercising territorial jurisdiction, which created modern state-centric governance, is being overlaid with (and perhaps is giving way to) heterarchic multi-level, multi-actor, non-territorial governance. I argue, though, that it is a good start that allows us to investigate potential paths of change systematically and comparatively.
\end{abstract}

Key Words: international system, heterarchy, global governance, international society, international human rights

lobalization and twenty-first-century international governance typically are

$G$ understood either as sui generis phenomena or through historical comparisons with the preceding "modern" era or medieval Europe. This essay instead employs an analytical framework of general applicability that allows us to think

*Jack Donnelly(Jack.Donnelly@du.edu) is the Andrew Mellon Professor and John Evans Professor in the Josef Korbel School of International Studies at the University of Denver. He has published extensively on the theory and practice of international human rights and on international relations theory.

The Korean Journal of International Studies Vol.14, No.1 (April 2016), 1-29.

http://dx.doi.org/10.14731/kjis.2016.4.14.1.1

(c) 2016 The Korean Association of International Studies 
comparatively and in broad structural terms about the development and transformation of contemporary international governance.

\section{ESTABLISHING TERMS OF REFERENCE}

Academic and popular discussions alike are awash in references to "global governance." Each term in that compound, however, has several standard senses and their conjunction, as Larry Finkelstein put it with only slight exaggeration in an article the first volume of the journal Global Governance, can mean "virtually anything" (Finkelstein 1995, 368). I thus begin by defining terms.

\section{GOVERNANCE}

"Governance" is commonly defined as "the action or manner of governing" or "controlling, directing, or regulating influence." This is very similar to standard definitions of "government": "the action of governing" or "authoritative direction or regulation." Both refer to processes and outcomes of governing, understood as "rul[ing] with authority" or "rul[ing] or regulat[ing] the affairs of (a body of men, corporation)."1

"Government," however, may also refer to a political institution, "the governing power in a state." 2 During the twentieth century this use became so predominant that another term seemed required if one wanted to talk about governing that was not limited to the governments of states. "Governance" became that term.

"Governance" today is commonly used in reference to national political rule ("the new governance"), the politics of development ("good governance"), and internationally. In all three contexts, "governance" was introduced to draw attention to the fact that governments alone can no longer (if they ever did) control, or even effectively steer, policy. Governing - governance - today requires varied and often complex forms of coordinated action by diverse public and private actors operating in many spheres and on multiple levels.

This contemporary context, however, should not obscure the fact that governance "is a word that has been used routinely over the course of many centuries to refer to the exercise of authority within a given sphere" (Hewitt de Alcántara 1998, 105).3 This is how I will use the term here.

\footnotetext{
${ }^{1}$ All definitions are from the Oxford English Dictionary.

${ }^{2}$ Oxford English Dictionary.

${ }^{3}$ Anthony Padgen (1998) traces contemporary uses back to Enlightenment republicanism and cosmopolitanism. Unfortunately, in emphasizing the historical novelty of contemporary forms of rule,
} 


\section{"GLOBAL GOVERNANCE" AND "INTERNATIONAL GOVERNANCE"}

In discussing governance internationally, the adjective of choice today is "global."4 For example, a Google Scholar search in January 2016 for "global governance" yielded more than 250,000 results - compared to less than 40,000 for "international governance." "Global governance" usefully suggests the link between the interest in international governance and "globalization." It also avoids any lingering statism in the term "international" and attractively refers to the largest (terrestrial) sphere of governance. Unfortunately, though, it suggests a global scope to processes that today are in fact largely inter-national, transnational, surpra-national, trans-regional, or regional. This is a fatal flaw for descriptive or analytical (rather than predictive or normative) uses.

Furthermore, "global governance" is often defined to refer to contemporary, historically contingent processes, 5 leaving us with no generic term for governance that is more than national in scope. I will use "international governance" - understanding "international" in the broad sense of indicating something "that transcends or goes beyond national boundaries or limits" - as that generic term. ${ }^{6}$

International governance, thus understood, is neither historically unusual nor conceptually surprising. It is as regular a feature of international societies as "national" governance is of "national" societies (or corporate governance is of corporations). In fact, the presence of international governance is no less characteristic of international relations than the absence of an international government. 7

governance is often defined to mean this kind of rule. For example, Robert Jessop (2003, 5) defines governance as "reflexive self-regulation," which he contrasts to anarchy and hierarchy. R. A. W. Rhodes (1996) defines governance as an activity of self-organizing networks. Vasudha Chhodry and Gerry Stoker $(2009,3,4)$ restrict governance to situations in which there is "no formal control system." Such stipulative definitions, which perversely make rule by a government not governance, resemble (re)defining "hat" to mean baseball cap because one has become interested in baseball.

${ }^{4}$ For reviews of the development and scope of this language, see Weiss (2000; 2013, ch. 1, 2), Brand (2005), Kustermans (2011), Hewson and Sinclair (1999) and Smouts (1998).

${ }^{5}$ For example, James Rosenau (2005b, 144), who has played a leading role in theorizing contemporary international governance - see especially Rosenau and Czempiel (1992) and Rosenau (1997) - defines global governance "as disaggregated complexity;" "a highly complex, disaggregated and minimally coordinated system of governance.” Klaus Dingwerth and Philipp Pattberg $(2006,297)$ understand "global governance as a perspective on world politics" and stress "the emergence of autonomous spheres of authority beyond the national/international dichotomy... [and] focuses on the complex interlinkages between different societal actors and governmental institutions." Miles Kahler (2009, 189) sees global governance as a phenomenon of "a world of fragmented sovereignty."

${ }^{6}$ Oxford English Dictionary.

${ }^{7}$ On international governance in states systems, see Figures 2, 3, and 4 . 


\section{STRUCTURE}

The other key term in the title of my paper is structure. I use it in the ordinary language sense of "the existing arrangement and mutual relation of the constituent parts of a material object, esp. as determining its distinctive nature or character" or "the arrangement and organization of mutually connected and dependent elements in a system or construct." 8 This corresponds to Waltz's definition of structure as the arrangement or ordering of the parts of a system (Waltz 1979, 80, 81, $88,99)$.

I reject, though, Waltz's tripartite (ordering principle, functional differentiation, distribution of capabilities) conception of the elements of political structures (Waltz 1979, 88-99). Elsewhere, I have sketched a comprehensive critique of the Waltzian conception and outlined an alternative (Donnelly 2009; 2012a; 2012b; 2015). Here I use that alternative to analyze contemporary international governance.

\section{FORMAL STRUCTURES OF INTERNATIONAL GOVERNANCE}

This section introduces four formal dimensions of structural differentiation, 9 which I use to identify two types of international systems of special contemporary relevance. In the following section I show that each type has characteristic patterns of governance.

\section{CENTRALIZATION, FUNCTIONAL DIFFERENTIATION, AND FOUR TYPES OF INTERNATIONAL SOCIETIES}

Social systems have centers, specially valued "places" around which social life is integrated, and peripheries, which are in varying ways and degrees removed from the center(s). As Edward Shils put it in his seminal 1961 essay "Centre and Periphery:"

Society has a centre. There is a central zone in the structure of society... membership in the society, in more than the ecological sense of being located in a bounded territory and of adapting to an environment affected or made up by other persons located in the same territory, is constituted by relationship to this central zone $(1961,117 ; 1975,3)$.

\footnotetext{
${ }^{8}$ Oxford English Dictionary.

${ }^{9}$ Structural differentiation also has essential substantive dimensions - most notably, characteristic norms and institutions and material features - which would increase the depth and precision of any account of the structure of international governance. That, though, is well beyond my scope here.
} 
A society may have more than one center. Relations between centers and peripheries may take many forms. Centrality may be rooted in normative, institutional, coercive, or productive resources. Whatever the forms, though, the creation and relations of centers and peripheries are central to the structure of most social systems.

The structural significance of functional differentiation is well known. Most functional differentiation is substantive, involving the differentiation of particular functions and their assignment to particular social positions and actors. The functional homogeneity or heterogeneity of actors, however, is an important formal dimension.

Combining functional homogeneity/heterogeneity with centralization yields a typology of international systems.

1) States have a single center that governs relatively homogeneous peripheries.

2) Empires have a single center that governs heterogeneous peripheries.

3) States systems have multiple relatively homogeneous centers.

4) "Heterarchies" have multiple heterogeneous centers.

States, empires, and heterarchies may be either international systems or units within larger (international or regional) systems. Both a world state and a world empire seem to me wildly implausible in the twenty-first century. Therefore, they will not be considered here. This leaves us with states systems and heterarchies; that is, multi-centric systems with (respectively) homogeneous and heterogeneous centers.

\section{SPATIO-POLITICAL ORGANIZATION}

Social and political systems can be profitably understood as spatially layered. A simple representation understands an international system as a bounded space that is subdivided, with each of those subdivisions further subdivided. This translates Waltz's layered model of system, units, and subunits into purely spatial terms.

Figure 1 presents the Waltzian model of "states" (functionally undifferentiated centers, located on the second level that rule homogeneous peripheries) in an "anarchic states system" (understood as without horizontal or vertical organization on or between the top two levels). 
Figure1. A Waltzian International System

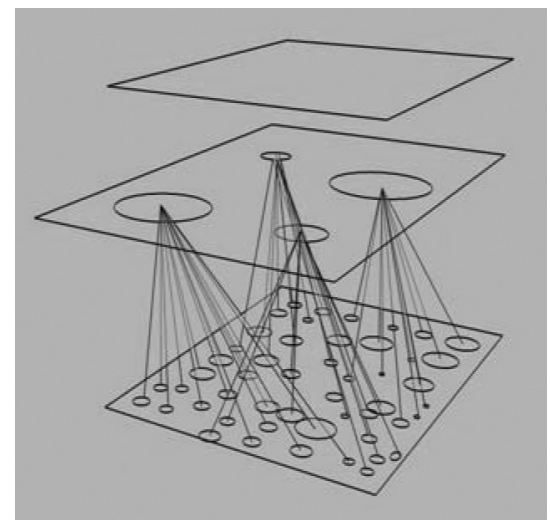

This representation is highly stylized. States systems may have significant elements of (horizontally generated) authority at "the system level" (e.g., international regimes and multilateral organizations) and not all the actors on "the unit level" (or the other levels either) need be homogeneous (consider, for example, the British and Dutch East India companies in the eighteenth century).

It is also an empirical, not a theoretical or conceptual, question how many levels a system contains and how they are arranged (and populated). Of most immediate relevance, contemporary globalization clearly requires at least four levels (adding a supra-unit or sub-systemic level) and perhaps five (dividing the lowest level of "subunits" into something like "regional" and "local" levels). In fact, there may not even be a clearly delineated system-wide level structure. In some scenarios of globalization, for example, individuals, groups, and communities come to stand in such varied relations to one another and to multiple "higher authorities" that we should not employ the notion of levels in modeling the system (Networks present an obvious alternative conceptualization.).

Nonetheless, spatio-political organization is an important formal feature of the structure of social and political systems. As we will see, especially Figure 5, the spatio-political order of heterarchies is radically different from that of states systems. And empires and states are organized in still different ways.

\section{STRATIFICATION}

Authority, status, and control are also typically layered in social and political systems. Such stratification (vertical differentiation) - the arrangement of social positions and actors in ranked or graded layers or levels - is of obvious structural significance. 
For our purposes here, we can ignore both unstratified systems (such as Hobbes' imaginary state of nature) and single-layer (egalitarian) systems (such as simple forager band societies). Our focus then is "hierarchical" systems; that is, systems with two or more ranked layers of authority or control.

Social systems typically have multiple hierarchies (of power, influence, wealth, birth, status, achievement, purity, etc.). An important formal difference in the structure of societies is whether those hierarchies tend to converge on a single axis of stratification or whether they fundamentally diverge or are "tangled." ${ }^{10} \mathrm{We}$ will see in the next section, states systems ideal-typically have convergent hierarchies. Heterarchies typically have divergent or tangled hierarchies.

\section{GOVERNANCE IN STATES SYSTEMS AND HETERARCHIES}

We now have the resources to specify, in very stripped down terms, the typical formal structures of governance in states systems and in heterarchies.

\section{GOVERNANCE IN STATES SYSTEMS}

A states system is composed of multiple similar centers. For simplicity, let us assume that the "states" in a states system are "states" as I defined them above, namely, single centers that govern relatively homogeneous peripheries. Historically, this corresponds to the late-modern states system of the twentieth century.

Figure 1 above provides a spatial representation of states system composed of "states." Governance in such a system is "single-level" governance; that is, provided primarily by actors on what Waltz calls "the unit level." It is also "singleactor" governance; that is, provided primarily by (homogeneous) actors of a single type ("states"). Governance in states systems also is fundamentally territorial. ${ }^{11}$

Figures 2-4 turn our attention to stratification in increasingly complex states systems. States are distinguished from non-state actors (pictorially, by ovals for states and other shapes for non-state actors). Horizontal lines mark strata. Wide (unfilled) arrows indicate official relations of authority. Thin arrows represent unofficial relations of control.

\footnotetext{
${ }^{10}$ The notion of tangled hierarchies is classically developed by Hofstadter (1979, ch. 20).

${ }^{11}$ On territoriality see the last paragraph of the section titled "Governance in Heterarchies."
} 
Figure 2. A Simple States System

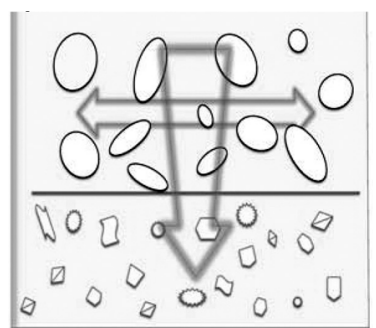

Figure 3. A Multipolar States System

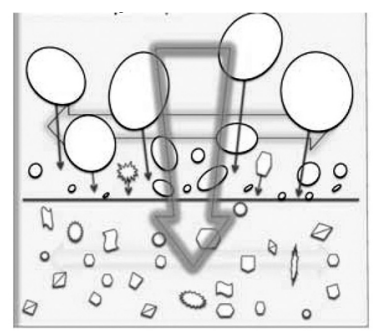

Figure 4. A Great Power States System

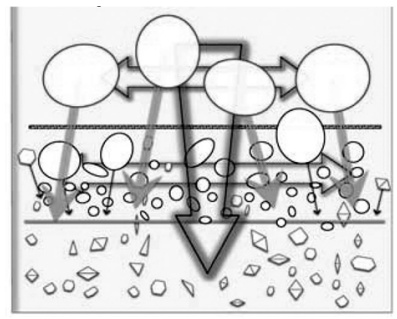

Central to these models - but rarely emphasized (and often denied) ${ }^{12}$ in contemporary IR theory - is the superordination of states and the subordination of non-state actors. States are officially superior to non-state actors (represented by the (bottom) horizontal line separating strata and by the wide vertical arrow indicating a relation of hierarchical authority). In fact, the legal differentiation and superordination of states defines a states system. Relations among states are "anarchic," in the sense of lacking a higher government. Relations in states systems, however, are hierarchical.

The simultaneous presence of national governments and absence of an international government makes governance largely national and governmental. Viewed from the perspective of the system, though, states systems are systems of radically decentralized governance (rather than systems without governance). And well-established states systems typically have considerable elements of (horizontally generated) international governance. For example, diplomacy, the balance of power, and peace conferences following general wars provided a surprising degree of governance in modern European international relations, especially in the heyday of the "old diplomacy."

In addition, as we move from Figure 2 to Figure 4 states become increasingly differentiated, with the great powers in Figure 4 having, if not a quasi-consensual authority, then an unofficial superiority to which most other states regularly acquiesce (or at least habitually do not resist). And, as in Figure 4, the multiple dimensions of great power superiority converge on a single axis of stratification.

\section{GOVERNANCE IN HETERARCHIES}

Figure 5 provides a representation of heterarchies parallel to Figure 1's representation of states systems. "Heterarchies" - the root arkhē (rule) or arkhon (ruler)

\footnotetext{
${ }^{12}$ Waltz $(1979,88)$ is the locus classicus.
} 
with the prefix hetero-, indicating difference, variety, or the other - are composed of multiple heterogeneous units organized in varying types of relations on varying scales. ${ }^{13}$ Different types of actors (represented by rectangles, ovals, and polygons) are variously related to actors at varying levels.

Figure 5. A Heterarchic International System

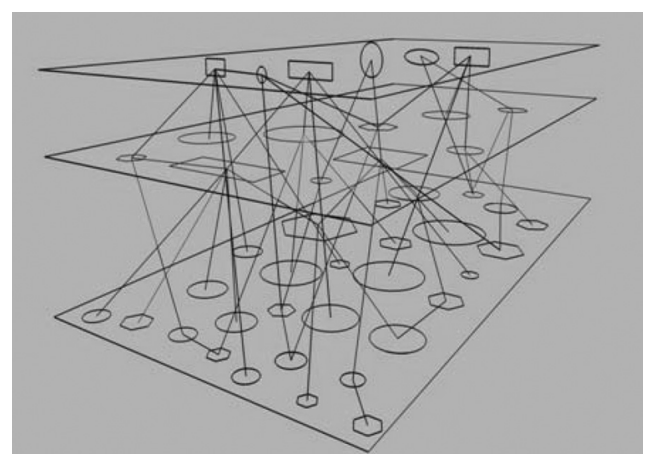

Governance in heterarchies is clearly multi-actor and multi-level, creating divergent (and often tangled) hierarchies. It is also fundamentally non-territori$a l$. In states systems, the concentration of functions in more or less "comprehensive" centers creates a fundamentally territorial form of politics. In heterarchies, the allocation of authority to more specialized functional centers, located in different places and operating at different scales, makes governance fundamentally non-territorial. A single territory typically is subject to multiple authorities. For example, in the early modern Holy Roman Empire, the Emperor, Electors, lesser princes (both secular and clerical), free cities, and imperial knights exercised different forms of authority, at widely varying scales, resulting in most places being subject to multiple (often competing) authorities. Today, the member states of the European Union are subject to the supreme jurisdiction of the European Court of Justice in many matters of economic and social policy, the supreme jurisdiction of the European Court of Human Rights in its functional domain, and various national courts on most other matters.

13 The term was coined in neuroscience (McCulloch 1945; 1965). It has been widely employed in cybernetics and computer science. "A program which has a structure in which there is no single "highest level', or 'monitor', is called a heterarchy" (Hofstadter 1979, 134). In the social sciences, heterarchy has been relatively widely employed in Archaeology - Crumley (1987) and Ehrenreich, Crumley, and Levy (1995) are the seminal works - and in the study of business organization, see Hedlund (1986), Stark (1999), Wall and van der Knaap (2012). 


\section{HETERARCHIC GOVERNANCE IN TWENTY-FIRST-CENTURY INTERNATIONAL SOCIETY}

We now are ready to consider the formal structure of governance of twenty-firstcentury international society. I have little if anything original to say about this much-discussed subject. My aim instead is to cast a novel (and I hope illuminating) light on familiar material.

Contemporary international society, I will argue, can best be modeled as a states system with a heavy heterarchic overlay - and may be moving towards a heterarchic international system with a heavy states-system residue. The overwhelming predominance of strong and robust multifunctional states exercising territorial jurisdiction, which created modern state-centric governance, is being overlaid with (and perhaps is giving way to) heterarchic multi-level, multi-actor, non-territorial governance.

\section{THE PERSISTENCE AND TRANSFORMATION OF STATES}

We should begin by noting that for all the talk of change, the state "remains the most important unit of the modern world" (Huber et al. 2015, 1). States are not only the most powerful actors in contemporary international society but the most important source of both national and international governance. Globalization has brought not the demise of the state but a new phase in its continuing transformation.

The high-modern states of the decades following World War II regulated an unprecedented range of issues and penetrated their societies in ways that would have seemed unimaginable even to their early-nineteenth-century predecessors. They monopolized not only the legitimate use of force but all jurisdiction. Political identity was predominantly national (state) identity. States even retained much of the economic predominance that they had established in the nineteenth and early twentieth centuries.

Externally, these post-WWII states claimed a right to exclude one another (and everyone else) from exercising autonomous authority within or coercive jurisdiction over them. They also were able to create new international and regional institutions and practices to collectively (inter-governmentally) address common interests and common aversions, allowing them to maintain their dominant role in international governance (Hanrieder and Zangl 2015, 256-258) even in the face of growing "interdependence" - a contemporary formulation that still prioritized the national and the inter-national.

"Globalization" suggests that the modern world of states (and their international organizations and inter-national regimes) is giving way to a post-mod- 
ern world that is coming to be organized if not really "globally" then at least not primarily nationally and inter-nationally. Twenty-first-century states, however, still do much more than their pre-twentieth-century predecessors.

Consider Europe. The state role in the economy in the 1810s was minor compared to the 2010s. National borders were much more porous. Central governments did little more than tax, wage war, and provide a thin system of law and order. Outside the capital cities and their environs, predominant identities usually were local or regional. ${ }^{14}$ And these nineteenth-century states were in turn much more tightly integrated, immensely more capable than, and quite different in character from their predecessors in the early-seventeenth century, in which monarchs reigned (and to a considerable extent still personally ruled) over aggregated realms that were governed by laws and institutions that varied by region. And they in turn were quite different from their early-fifteenth-century predecessors. In other words, we are witnessing the latest phase in the continuing transformation of the state. The relative decline of the state should not be confused with its demise.

\section{CHANGING PATTERNS OF GOVERNANCE}

The persisting centrality of states, however, does not mean that the structure of the international system, or international governance, remains unchanged. Even if international society remains fundamentally a states system, there is an increasingly heavy overlay of heterarchy, involving the rise of non-state actors, changes in the character and functions of states, and the re-segmenting, re-stratifying, and re-centering of international relations.

Consider Europe (again). From the thirteenth to the twentieth centuries, authorities and capabilities were slowly and fitfully (but ultimately steadily) transferred from local and provincial authorities - and from society and the economy - to the state. Today, authorities and capabilities are not exactly moving back to where they once resided. They are, however, being reallocated and relocated.

"Nationally," authority and responsibility are increasingly being devolved to provinces, regions, and even localities. No less importantly, "multi-stakeholder" governance is becoming increasingly common. This is reconstructing the boundaries between public and private and between state, society, and economy which had been constructed in very particular ways by twentieth-century states

\footnotetext{
${ }^{14}$ For example, Eugen Weber's classic book Peasants into Frenchmen (1976) deals with the rise of a national identity in rural France - which is usually seen as a European leader in national centralization - in the last third of the nineteenth century.
} 
(and in different ways by their nineteenth-century predecessors, and in still different ways by their predecessors).

Contemporary changes in international governance have been at least as substantial. After the abdication of Charles V in 1555 (and the ensuing division of the "Spanish" and "Austrian" Hapsburg domains), states faced no serious systematic external challenge. ${ }^{15}$ Intervention and war, of course, remained common. They involved, however, actions by one state or monarch in or against another; actions of coordinate, not superordinate, authorities. No supranational or transnational actor or institution could claim, or even plausibly aspire to, a higher authority that had even the tiniest chance of being realized in practice.

By the Treaty of Utrecht (1713), which ended the wars of Louis XIV, sovereign "states" dealt with one another according to formal and informal rules that they set for themselves. And the fundamental rule of their relations was mutual recognition of one another's sovereignty. This created both the external conditions for a state monopoly on internal governance and the foundations of a system of limited international governance monopolized by states.

During the last half of the nineteenth century, the number and significance of international conferences and organizations grew ${ }^{16}$ - although they almost always were forums for inter-governmental action rather than autonomous actors in their own right. Transnational nongovernmental organizations also began to emerge to some prominence, especially in the campaigns against the slave trade and slavery and in humanitarian politics (as symbolized by the creation of the International Committee for the Red Cross in 1863). Businesses also became increasingly significant international actors, as did the international trade union movement.

These trends intensified in the twentieth century, especially following each of the world wars. By the 1970s, the monopoly of state governments on international governance was beginning to unravel. International and regional organizations acquired growing authority and capabilities that they increasingly exercised in conjunction with, and occasionally independently of, states. There was an explo-

\footnotetext{
${ }^{15}$ Seventeenth-century fears of the Hapsburgs were, at best, exaggerated. And although international reactions against Louis XIV were sometimes formulated as fears over the rise of a "universal monarchy," by the end of the seventeenth century the standard fear was for the maintenance of a balance of power in the European states system (in order to protect the autonomy of its (great power) members).

${ }^{16}$ Reinalda (2009) provides a good general overview. Murphy (1994) focuses on the regulation of industry and technology. Hill (1929) remains a useful survey of the development of the conference form, with special attention to peace and security issues. David Mitrany's The Progress of International Governance (1933) is a classic interwar work of analysis and advocacy.
} 
sion of new nongovernmental organizations, both in traditional economic and development and peace and security issues and in "new issues" such as human rights and the environment. And "multinational corporations" began to transition from national firms with multinational operations to "transnational enterprises" with an increasingly global perspective. By the end of the twentieth century, we were beginning to see an unprecedented move of authority and capabilities "up" to regional and international regimes and transnational actors. International governance was becoming increasingly functional, multi-level, and multi-actor; that is, heterarchic.

\section{EMERGING HETERARCHY}

Authorities previously held by states are increasingly being reallocated among actors and institutions with different bases of authority, different ways of operating, and different stakes in the game. Although the categorical distinction between states and non-state actors remains important, there is no longer the stark divide of a century ago. And the politically privileged position of states is clearly on the decline. ${ }^{17}$

Even where states retain formal authority or practical predominance, they often are able to act effectively only through mechanisms that possess some degree of more or less autonomous supranational authority (e.g., the regulation of international monetary relations or the global trade regime centered on the World Trade Organization) or in cooperation with various non-state actors (e.g. in the provision of development assistance and humanitarian assistance). In other areas, new regulatory mechanisms have emerged that are not focused on states. "Standard setting" in various technical areas ${ }^{18}$ is a striking example of this emergence of "private governance." 19 In rare instances (e.g., the European Union), states have been both formally and effectively subordinated to supranational authorities.

In the contemporary world, governance increasingly involves a tiered structure in which a) higher levels of authority are of greater territorial extent but b) some types or subjects of authority are reserved to "lower" levels. Governance thus is becoming increasingly spread across levels.

Most of these changes reallocate and relocate authority "up" to supranational

${ }^{17}$ Avant, Finnemore, and Sell (2010) is an excellent and wide-ranging collection that focuses on the diversity of "governors" in contemporary international governance.

${ }^{18}$ Murphy and Yates (2009) provides a detailed study of the International Organization for Standardization (ISO).

${ }^{19}$ Sell (2003) is a classic work dealing with intellectual property rights. 
organizations or international regimes and/or "down" to regions, provinces, or other subnational authorities. Sometimes, though, new authorities or capabilities are created (and allocated, in whole or in part, to transnational or supranational actors) that increase the amount of governance in the system. (Standard-setting in high-tech industries again provides a good example.) Occasionally, governance authority or capability is lost. This is a common concern as corporations move production, and even their home base, to reduce taxes or escape regulation.

But although authorities and capabilities clearly are moving away from states, they are moving in many different directions that vary with time, place, and issue area (rather than moving "towards" any particular places or actors). This may reflect a process of transition that, because it is only beginning, has yet to (appear to) move in any particular direction(s). It may, however, reflect a more fundamental change.

Centers are of special analytic significance when functions are concentrated in a single place (e.g., empire) or type of actor (e.g., states) or when relatively few functions are divided among a few types of actors. When numerous functions are allocated to numerous actors operating at many levels, "the center" of society may become so disaggregated and dispersed that centrality provides limited analytical leverage. As heterarchies become more complex and diverse, functional differentiation becomes more illuminating that centralization - especially when, as in the contemporary world, there is no clear normative center and no deeply shared common identity.

\section{CASE STUDY: THE HETERARCHIC GOVERNANCE OF INTERNATIONAL HUMAN RIGHTS}

We can illustrate the emergence of heterarchy with the case of human rights. I do not mean to suggest that there is anything typical about the international governance of human rights. Human rights, however, is an area of obvious interest and significance. It is not an extreme outlier with respect to the degree of change from the prior pattern of statist governance. Human rights also illustrates some of the diversity of heterarchic changes in contemporary international governance. And it is a topic where I happen to have some substantive expertise.

In the classic statist model, human rights was almost exclusively the preserve of states acting nationally. (How a state treated "its" citizens on "its" territory was its business (alone).) Over the past three or four decades, though, the international governance of human rights has become more complex - and in Europe it has become fully heterarchic.

A global human rights regime has emerged around an authoritative body of international human rights law, centered on the 1948 Universal Declaration of 
Human Rights and the 1966 International Human Rights Covenants, that can reasonably be described as universally binding on all states (and other international actors that either engage in force or exercise legal authority over a population or territory). Strong universal human rights norms, however, are supported (at the global level) only by generally weak and fundamentally state-centric implementation and enforcement mechanisms. This has produced a system of national implementation of international human rights norms. The international politics of human rights thus remains, with some notable exceptions, largely a matter of "shame and blame" - although both the absolute and the relative power of the blamers is increasing and the most shameful violators are also increasingly subject to (usually modest) material sanctions.

States today are subject to extensive international monitoring of their human rights practices. Formal multilateral mechanisms include both reporting to a number of expert bodies and the system of Universal Periodic Review by the Human Rights Council of the United Nations. ${ }^{20}$ Unofficial monitoring, by both national and international nongovernmental organizations, is at least as significant. ${ }^{21}$ In addition, individual states, most notably the United States in its annual Country Reports on Human Rights Practices, monitor the human rights performance of other states (especially those to whom they provide development assistance).

The information generated by these monitoring activities is regularly put to use by a wide variety of national, bilateral, transnational, international, and regional advocates. States are regularly subject to criticism of their human rights practices by other states, national and transnational NGOs, and regional and international organizations. They are also subject to more coercive action, especially by other states, many of which regularly alter the character of their relations (including development and security assistance) on the basis of human rights performance. ${ }^{22}$ In extreme cases - e.g., South Africa in the 1970 and 1980s, Burma/ Myanmar in the 1990 s and 2000s, and contemporary North Korea and Zimbabwe - gross and persistent systematic violators, although they retain full sovereign rights, have been consigned to a pariah status that substantially reduces the benefits they obtain as members of international society.

Furthermore, coercive international action against genocide is now widely

${ }^{20}$ For introductory overviews of global multilateral human rights mechanisms, see Donnelly (2013a, ch. 5, 7; 2013b) and Forsythe (2012, ch. 3), which provide guides to further reading.

${ }^{21}$ See Donnelly (2013a, ch. 10) and Forsythe (2012, ch. 7).

${ }^{22}$ For overview of human rights in foreign policy, see Donnelly (2013a, ch. 9; 2013b, ch. 12) and Forsythe (2012, ch. 6). 
accepted as legitimate. ${ }^{23}$ Genocidal regimes have become subject to international peacekeeping operations (such as the joint UN-African Union force that has operated in the Darfur region of Sudan since 2007). In a few cases (East Timor and Kosovo in 1999), military measures have successful expelled or replaced a genocidal regime. In addition, the International Criminal Court exercises criminal jurisdiction over individuals, including national leaders, guilty of genocide (as well as crimes against humanity and war crimes). ${ }^{24}$ In this limited area, states have largely lost the authority they formerly had to treat their citizens as they saw fit. Debate continues to rage over which (if any) armed interventions against genocide are legitimate in the absence of authorization by the UN Security Council. There is little question, though, that enforcement authority with respect to genocide has been transferred from states to "the international community."

Regional organizations 25 introduce a further element of heterarchy. Modestly intrusive regional monitoring and advocacy regimes exist within the Organization of American States and the African Union. Very rudimentary human rights monitoring procedures are being established within the Association of Southeast Asian States. And in Europe, a robustly heterarchic multi-level and multi-actor system of governance has been established.

All 47 member states of the Council of Europe (CoE), which have a total population of over 800 million, recognize the compulsory jurisdiction of the European Court of Human Rights (ECHR), which makes binding legal decisions on "applications" from individuals alleging violations of the rights enumerated in the European Convention on Human Rights. In 2015, the Court registered 40,650 new applications and delivered judgments on 2,441 (aggregated into 823 decisions). ${ }^{26}$ This is more than five times the petitions received in 2015 by the U. S. Supreme Court - which exercises jurisdiction over about 40 percent of the population of the $\mathrm{CoE}$ countries - and more than ten times the number of decisions. ${ }^{27}$

Equally importantly, in every CoE state the European Convention have a status superior to national statutes (Stone Sweet 2012, Appendix 1, 84-85) ${ }^{28}$ and indi-

\footnotetext{
${ }^{23}$ See Donnelly (2013a, ch. 13; 2013 b, ch. 15), which provides extensive citations to the (now quite considerable) literature.

${ }^{24}$ Stahn (2015) provides a comprehensive overview.

${ }^{25}$ On regional human rights regimes, see Donnelly (2013a, ch. 6) and Forsythe (2012, ch. 5).

${ }^{26}$ See European Court of Human Rights, "Analysis of Statistics 2015," 4-5. The great limitation of this mechanism, however, is that the Court cannot invalidate national legislation but only provide compensation to individual victims. Recalcitrant states thus often continue their violations, producing a series of essentially identical cases returning to the Court - although even a country like Russia is generally scrupulous in executing the judgments of the ECHR.

${ }^{27}$ See Supreme Court of the United States, “2015 Year-End Report on the Federal Judiciary,” 13.
} 
vidual litigants in national courts can appeal directly to the Convention. This often results in a complex entanglement of legal hierarchies created by conflicts between constitutional courts, which in most countries in the region have exclusive authority to invalidate national laws, and ordinary courts (including national supreme courts), which can apply regional human rights law on behalf of individual litigants. ${ }^{29}$

The strength of the CoE regime is further enhanced by the fact that the ECHR interprets the Convention not according to the understandings that prevailed at the time of its adoption (in the early 1950s) but according to current regional patterns of practice. The ECHR has even begun to apply the Convention beyond the borders of Europe (Stone Sweet 2012, 79-82).

In addition, the Council of Europe Commissioner for Human Rights is a leading regional human rights advocate. The Commissioner manages substantial monitoring and promotion programs that include visits to individual countries, "thematic" advocacy and education (on issues including children's rights, LGBTI rights, media freedom, migration, persons with disabilities, and Roma and Travellers), and support for human rights defenders. And especially strong regional supervisory and investigative procedures exist with respect to torture, including the right of the European Committee for the Prevention of Torture to visit any site of detention its choses and to have unlimited access to all places and persons in those sites.

A parallel system of regional jurisdiction operates for the 28 members of the European Union (EU). The supreme legal authority of the Court of Justice of the European Union is of considerable human rights significance in the areas of social policy and economic and social rights $3^{30}$ and nondiscrimination. ${ }^{31}$ In addition, the European Commission, the European Parliament, and the European Council have important legislative powers - EU legislation supersedes national law - and

${ }^{28}$ On the national impact of the Court, see Keller and Stone Sweet (2008).

${ }^{29}$ See, for example, Garlicki (2007) on Germany, Italy, Poland, and France and Sadurski (2014, 35-42) on Central and Eastern Europe. The situation is even more complicated in countries with functionally specialized courts, such as France and Germany. For an illuminating case study, considered in the context of national legal pluralism, see Stone Sweet and Stranz (2012).

${ }^{30}$ In the Council of Europe system, the European Convention is largely restricted to civil and political rights. Economic and social rights are specified in the European Social Charter. The European Committee of Social Rights, which supervises the implementation of the Social Charter, is authorized (only) to draw "conclusions" about violations that even though they are not legally binding often have political impact.

31 "Today, across Europe, EU fundamental rights are a more important source of non-discrimination law than are national constitutions" (Stone Sweet 2012, 65). 
the Commission has important supervisory powers as well.

All European states are also members of of the Organization for Security and Cooperation in Europe (OSCE), which operates a variety of promotion and monitoring programs, including highly developed programs addressing democratization, elections, gender equality, human trafficking, media freedom, minority rights, policing, rule of law, and tolerance and nondiscrimination. The OSCE Office for Democratic Institutions and Human Rights monitors national situations, provides advice and assistance to states, and supports individuals and civil society organizations. Its Director is also an important regional advocate for human rights, as is the OSCE High Commissioner for National Minorities.

No less importantly, national, regional, and international civil society organizations play a major advocacy role, both with respect to human rights in general and many individual rights. Especially in the more democratic countries of the region, the authority and capabilities of states can sometimes be effectively challenged by the moral authority and political influence of national and transnational human rights NGOs.

In the global human rights regime, states retain a central role in every country. In the substantial majority of the world's countries they retain full final legal authority (except with respect to genocide). But in Europe, which includes a quarter of the world's countries and more than ten percent of the world's population, a robust multi-level multi-actor heterarchy has been established. And in most other countries, national and international human rights advocates have become regular participants in processes of national human rights governance that previously were monopolized by national governments.

\section{"INTERNATIONAL RELATIONS" IN THE TWENTY FIRST CENTURY}

One consequence of these changes has been the problematization of the very notion of "international relations." The (slow, uneven, and immensely difficult) "rise of the modern state" created a world of increasingly sharply defined "insides," over which central governments exercised superordinate authority. These states dealt with each other in the "outside" world as peers, who were both distinguished from (and superior to) other types of actors and subject to sharp internal differences of status and power. Georg Schwarzenberger nicely referred to states as the aristocrats of international society and great powers as the oligarchs among those aristocrats, non-state actors being the "commoners" of this system(1951, ch. 6, 7).

This world, as it were, "produced" the phenomenon of international relations (understood as a particular type of "foreign affairs" or "external relations"). It thus seems to me no coincidence that the term "international" was, according to 
the Oxford English Dictionary, first used in print by Jeremy Bentham in 1780; that is, when the modern states system had become well-established and when modern states were coming into being and beginning to see themselves less as agglomerations of different peoples and more as distinct nations.

In heterarchies, however, the absence of sharply differentiated "insides" and "outsides" - or, conversely, the proliferation and overlap of insides and outsides - makes distinguishing "national" and "international" relations problematic. Because authority is neither allocated territorially nor concentrated in a single center, heterarchies in an important sense have neither "international relations" nor "domestic politics." Social and political spaces simply are not organized in a way that this distinction illuminates.

These changes also call into question the distinction between states and nonstate actors. (The category "non-state actor" is largely an artifact of a world dominated by states. For example, applied to medieval Europe, the distinction between states and non-state actors is deeply uninformative and wildly anachronistic.) They also make problematic the associated three level structure - first image, second image, and third image; man, the state, and Waltz - that contemporary IR often takes for granted.

\section{ALTERNATIVE FRAMES OF ANALYSIS}

As I suggested above, my contribution here, such as it is, involves reconceptualizing familiar changes. An appropriate way to conclude thus is to compare my account with leading alternatives. Heterarchy, I will argue, although not without its own problems, provides a more comprehensive and more penetrating frame that also avoids many analytical shortcomings of the alternatives.

\section{GLOBAL GOVERNANCE}

As noted above, the language of global governance, although quite common, is descriptively inaccurate. Although globalization has made it (not im) plausible to talk about governing the globe, international governance today is almost never performed globally, in the sense of at the global level. Contemporary international governance remains largely inter-national, trans-national, and supra-national. "Global governance" thus is, at best, a fundamentally misleading (or purely predictive or prescriptive) framing.

\section{PLUS ça CHANGE}

We still sometimes encounter arguments, especially from realists, that nothing 
fundamental has changed..$^{2}$ Such accounts rightly emphasize important elements of continuity. They also, however, ignore or deny no less significant structural changes. Although states remain the most important class of international actors, their old territorial monopolies are increasingly a thing of the past. And their near monopolization of international governance has generally given way to a situation of, at best, state predominance. In a few areas, states have lost final authority all together.

The states system that largely exhausted international relations in the first half of the twentieth century has been overlaid by a heterarchic system. And the gap between this twenty-first-century reality and the model of "states in anarchy" is increasing - steadily, and perhaps even at an accelerating pace. Heterarchy provides the conceptual resources to give full credit to these changes without denying the continuing importance of states and inter-state relations - both by leaving space for states as major actors in a heterarchic system and by allowing for a hybrid model of a heterarchic states system. In addition, the underlying conception of structure allows us to understand continuity, where it appears, as an empirical feature of the world (rather than an artifact of a narrow definition of the structure of international systems, in which only the creation of a global state or empire counts as major structural change).

\section{HORIZONTAL AUTHORITY}

Contemporary changes in international governance are sometimes described as involving the growth of "horizontal" authority. For example, James Rosenau argues that "pockets of vertical hierarchies" remaining from the modern states system are likely to continue to operate alongside "new horizontal arrangements" (2005a, 86). Oran Young argues that "taken together, regimes form a horizontal rather than a vertical or hierarchical system of public order" $(1999,6)$.

In fact, though, supranational authorities, although horizontally generated, stand above - in a vertical, hierarchical relation to - states. Heterarchies are not non-hierarchical. They are differently hierarchical.

Every system of stratification creates both inequalities between ranks and equalities within ranks. In a states system, those inequalities and equalities are relatively simple and relatively consistent across the system, creating something very much like a hierarchy in the system. As international society becomes more heterarchic, however, we need to think in terms of hierarchies, in the plural; of multiple, divergent, and even cross-cutting systems of equalities and inequalities.

${ }^{32}$ Mearsheimer (1994/95; 1995) is a classic example. 
In fact, as divergent hierarchies proliferate, the distinction between horizontal and vertical increasingly becomes problematic. Who is above, below, or alongside whom varies with place and issue areas. Heterarchic relations may even become so complex and varied that we need to subordinate, or even abandon, thinking in terms of layers; of horizontal and vertical organization. Networks provide an obvious alternative framing.

\section{"FRAGMEGRATION"}

Much more insightful is James Rosenau's notion of "fragmegration," which he defines as "processes of integration and fragmentation [that] are unfolding simultaneously and endlessly interacting as the migration of authority [away from states] moves helter-skelter and in contradictory directions" (2005a, 75) 33 This does indeed identify a very important dimension of change in the contemporary world: politics today is both increasingly fragmented and increasingly integrated in new and varied ways, reversing the trend of the preceding several centuries of concentrating authority and capabilities in states.

Processes of fragmentation and integration, however, are universal features of social and political systems, both national and international. States systems are "fragmegrated" - differentiated and integrated - in one way, empires in another, and heterarchies in many other ways. I have in effect argued that stratification, centralization, and functional differentiation get at these processes in an insightful way that allows disciplined comparisons across a wide variety of cases. The "fragmegration" of recent decades, in other words, involves particular forms of (re-)segmentation, (re-)centralization, and (re-)stratification of national and international societies.

\section{MULTI-LEVEL GOVERNANCE}

Multi-level governance, which is probably the most common alternative conceptualization, 34 clearly identifies changes of great importance. Most political systems, however, have elements of multi-level governance. 35 And what seems

33 The concept is more fully elaborated in Rosenau (1997).

34 The concept, although applied especially in the context of the EU, has general applicability. See, for example, Hooghe and Marks (2001; 2003) and Bache and Flinders (2004). Schakel, Hooghe, and Marks (2015) is a good brief recent survey.

${ }^{35}$ Federal and confederal systems are multi-level in a strong sense of that term. Even in national systems with a very strong center, certain tasks are carried out primarily at the local or provincial level. Similarly, states systems, where most governance is provided at the level of the state, usually have at least limited international governance, making governance multi-level. The utility of the frame, however, can be significantly enhanced by contrasting multi-level governance with the pri- 
essential today is not simply that governance is multi-level but that it increasingly is sub-national, national, and supra-national; that is, that it occurs at and across all three levels defined in reference to the state.

The frame of multi-level governance also is radically incomplete, ignoring the no less important phenomenon of multi-actor governance. There is no good reason to privilege multi-level over multi-actor. Consider, for example, the rise of global firms and global finance, which has forced multi-level (and multi-actor) governance on largely resistant and dissatisfied states and citizenries.And in many (most?) instances, the two processes are interdependent, multi-level governance fostering multi-actor governance and multi-actor governance foster multi-level governance.

"Multi-actor multi-level governance" is, admittedly, an awkward formulation. "Heterarchy" has all the obvious disadvantages of a neologism. Nonetheless, these formulations, I have suggested, are both descriptively more accurate and analytically more penetrating. They seem to me, all things considered, a clear analytical advance.

\section{NEO-MEDIEVALISM}

Neo-medieval governance is a formulation that predates by decades talk of globalization. The emergence of a "new medievalism" was considered (and rejected) by Arnold Wolfers $(1962,241-242)$ in the early 1960 s and (at greater length and with greater impact) by Hedley Bull $(1977,254-255,264-276)$ in the mid-1970s. In the mid-1990s, the concept caught on and became linked to issues of international governance. $3^{6}$ The underlying intuition (which seems to me sound) is that "it will be easier to understand the post-international world by turning to the dynamics of the pre-international world" (Friedrichs 2001, 477).

Jörg Friedrichs suggests a tight analogy in which the integrating medieval universalisms of Church and Empire are matched by "the antagonistic organizational claims of the nation-state system and the transnational market economy" (2001, 475). This seems to me forced, at best.

But whether the analogy is tight or loose - in most of the literature, "neomedieval" functions simply as a vague metaphor - "medievalism," whether old or

marily one-level governance of state systems. See, for example, Marks, Hooghe, and Blank (1996), one of the first major uses of the term.

${ }^{36}$ Kaplan (1994) was perhaps the most discussed argument (in part because of his exceedingly bleak vision of "the coming anarchy"). More moderate visions, focusing explicitly on governance, include Kobrin (1999) and Held (1995, 137-140). Zielonka (2006) is a particularly interesting application of the concept to thinking about the evolution of Europe in fundamentally non-statist terms. 
new, is not an analytical category. Heterarchy is. It thus allows us to systematically compare and contrast these (and other) cases, rather than just draw attention to certain similarities that are especially striking when these cases are contrasted to the modern sates system.

This is especially important because, other than the fact that both are heterarchic, the world of the "high middle ages" (the eleventh, twelfth, and thirteenth centuries) and that of twenty-first-century globalization are fundamentally dissimilar. The medieval world was profoundly local with a thin, largely religious, universal cultural overlay and very weak "intermediate" political authorities (kings, dukes, bishops, abbots, and other secular and clerical princes). The idea of Christendom was coupled with a daily social reality of lordship or seigneurialism (and in poorer areas and bad times, something very close to village or manorial autarky) lightly overlaid by princely "rule" (which usually amounted to little more than (often predatory) military "protection" and very limited access to legal proceedings $)^{37}$ - although from the "twelfth century Renaissance" on, there was a small but significant transnational civil society.

The world of the twenty-first-century is much more richly and deeply multilevel. A global economy, and a global communications and transportation infrastructure, have made local isolation the exception rather than the overwhelming norm. Not just a privileged few but ordinary people (or at least a substantial privileged many) are able to operate translocally and transnationally. No less importantly, politics and society at all levels are much more complex and much more open to a wide range of possibilities. And the diversity of actors and venues is striking.

Heterarchy, it seems to me, clearly and rather precisely indicates what these two periods share without suggesting any other similarities - which are few. The world of the twenty-first century is not becoming "more medieval" in any strong or substantively interesting sense of that term. It is becoming more heterarchic.

\section{THE EMBEDDED STATE}

Comparative Politics has long talked about states being embedded in societies. ${ }^{38}$ Recently, the notion of an embedded state has been turned inside out.39 States

\footnotetext{
${ }^{37}$ The principal exception was in those areas - southwestern German, Castile, and especially northern Italy - where cities became major political actors. Here too, though, localism predominated, although the units were urban-centered and, especially in Castile and Italy, larger and more complex.

${ }^{38}$ Evans (1995) was especially influential.

${ }^{39}$ See, for example, Hanrieder and Zangl (2015) and Jacobsson, Pierre, and Sundström (2015).
} 
today are increasingly embedded in complex transnational, international, and supranational practices and institutions. And so long as states continue to play a predominant role in national and international governance, there will be much to be said for this framing.

Like most of the other formulations considered above, though, "the embedded state" is focused principally on distinguishing the contemporary world from what immediately preceded it. It works well for the contemporary hybrid system. It does not, however, link up to any broader analytical typology. Notions of centralization, stratification, and functional differentiation, I have in effect argued, provide analytical resources to explore systematically and comparatively how states are embedded and how this matters.

\section{HETERARCHY}

Heterarchy, it must be admitted, is not without analytical shortcomings. Most importantly, as I have already noted, that international relations is becoming more heterarchic is of far less analytical importance than how and where it is becoming heterarchic. Furthermore, although a huge diversity of types is encompassed in the category of heterarchy - one might even say that "heterarchic" tells us more about how a system is not structured than how it is - I am unable (even if I had the space and the patience of the reader) to offer anything close to a framework for analyzing heterarchies.

Nonetheless, heterarchy, understood in terms of centralization, stratification, and functional differentiation, provides the analytical resources to map contemporary governance practices in some detail and with considerable precision. It also allows us to compare contemporary forms and processes, using an independently derived set of categories of broad applicability and considerable analytical power, with both historical examples and possible paths of change. It is only to start to the story to say that governance in the twenty-first century, although still centered on states, is becoming increasingly heterarchic. It is, though, I would argue, a good start.

\section{REFERENCES}

Avant, Deborah D., Martha Finnemore, and Susan K. Sell, eds. 2010. Who Governs the Globe? Cambridge: Cambridge University Press.

Bache, Ian and Matthew Flinders, eds. 2004. Multi-level Governance Oxford: Oxford University Press.

Brand, Ulrich. 2005. "Order and Regulation: Global Governance as a Hegemonic 
Discourse of International Politics?” Review of International Political Economy 12(1), 155-176.

Bull, Hedley. 1977. The Anarchical Society: A Study of Order in World Politics. New York: Columbia University Press.

Chhotray, Vasudha and Gerry Stoker. 2009. Governance Theory and Practice: A Cross-Disciplinary Approach. Houndsmills, Basingstoke: Palgrave Macmillan.

Crumley, Carole L. 1987. "Celtic Settlement Before the Conquest: The Dialectics of Landscape and Power." In Carole L. Crumley and William H. Marquardt eds., Regional Dynamics: Burgundian Landscapes in Historical Perspective, San Diego: Academic Press, 403-430.

Dingwerth, Klaus and Philipp Pattberg. 2006. "Global Governance as a Perspective on World Politics." Global Governance 12(2), 185-203.

Donnelly, Jack. 2009. "Rethinking Political Structures: From 'Ordering Principles' to 'Vertical Differentiation' - and Beyond.” International Theory 1(1), 49-86.

. 2012a. "The Differentiation of International Societies: An Approach to Structural International Theory." European Journal of International Relations 18(1), 151-176.

. 2012b. "The Elements of the Structures of International Systems." International Organization 66(4), 609-643. . 2013a. International Human Rights. 4th ed. Boulder: Westview Press. . 2013b. Universal Human Rights in Theory and Practice. 3rd ed. Ithaca: Cornell University Press.

. 2015. “The Discourse of Anarchy in IR." International Theory 7(3), 393425.

Ehrenreich, Robert M., Carole L. Crumley, and Janet E. Levy, eds. 1995. Heterarchy and the Analysis of Complex Societies. Arlington: American Anthropological Association.

European Court of Human Rights. 2016. "Analysis of Statistics 2015." Accessed at http://www.echr.coe.int/Documents/Stats_analysis_2015_ENG.pdf (March 14, 2016).

Evans, Peter B. 1995. Embedded Autonomy:States and Industrial Transformations. Princeton: Princeton University Press.

Finkelstein, Lawrence S. 1995. "What Is Global Governance?” Global Governance 1(3), 367-372.

Forsythe, David P. 2012. Human Rights in International Relations. 3rd ed. Cambridge: Cambridge University Press.

Friedrichs, Jörg. 2001. “The Meaning of New Medievalism.” European Journal of 
International Relations 7(4), 475-501.

Garlicki, Lech. 2007. "Constitutional Courts versus Supreme Courts." International Journal of Constitutional Law 5(1), 44-68.

Hanrieder, Tine and Bernhard Zangl. 2015. "The Embedded State: The New Division of Labor in the Provision of Governance Functions." In Stefan Leibfried, Eevelyn Huber, Matthew Lange, Jonah D. Levy, Frank Nullmeier and John D. Stephens eds., The Oxford Handbook of Transformations of the State, Oxford: Oxford University Press, 253-268. Hedlund, Gunnar. 1986. "The Hypermodern MNC: A Heterarchy?” Human Resource Management 25(1), 9-35.

Held, David. 1995. Democracy and the Global Order: From the Modern State to Cosmopolitan Governance. Stanford: Stanford University Press.

Hewitt de Alcántara, Cynthia. 1998. "Uses and Abuses of the Concept of Governance." International Social Science Journal 50(155), 105-113.

Hewson, Martin and Timothy J Sinclair. 1999. "The Emergence of Global Governance Theory.” In Martin Hewson and Timothy J Sinclair eds., Approaches to Global Governance Theory, Albany: SUNY Press, 3-22.

Hill, Norman Llewellyn. 1929. The Public International Conference: Its Function, Organization and Procedures. Stanford: Stanford University Press.

Hofstadter, Douglas R. 1979. Gödel, Escher, Bach: An Eternal Golden Braid. New York: Basic Books.

Hooghe, Liesbet and Gary Marks, eds. 2001. Multi-level Governance and European Integration. Lanham: Rowman \& Littlefield Publishers.

. 2003. "Unravelling the Central State, But How? Types of Multi-Level Governance.” Reihe Politikwissenschaft. Vienna: Institut für Höhere Studien, Wien.

Huber, Eevelyn, et al. 2015. "Introduction: Transformations of the State." In Stefan Leibfried, Eevelyn Huber, Matthew Lange, Jonah D. Levy, Frank Nullmeier and John D. Stephens eds., The Oxford Handbook of Transformations of the State, Oxford: Oxford University Press, 1-32.

Jacobsson, Bengt, Jon Pierre, and Göran Sundström. 2015. Governing the Embedded State: The Organizational Dimension of Governance. Oxford: Oxford University Press.

Jessop, Robert. 2003. "Governance, Governance Failure, and Meta-Governance." Presented atPolicies, Governance, and Innovation for Rural Areas, Universita della Calabria. November 21-23.

Kahler, Miles. 2009. "Global Governance Redefined." In Andrew Sobel ed., Challenges of Globalization: Immigration, Social Welfare, Global Governance, Milton Park Abingdon: Routledge, 174-198. 
Kaplan, Robert D. 1994. "The Coming Anarchy." The Atlantic Monthly 273(2), 44-76.

Keller, Helen and Alec Stone Sweet, eds. 2008. A Europe of Rights: The Impact of the ECHR on National Legal Systems. Oxford: Oxford University Press.

Kobrin, Stephen. 1999. "Neomedievalism and the Postmodern Digital World Economy." In Jeffrey A. Hart and Aseem Prakash eds., Globalization and Governance, New York: Routledge, 165-187.

Kustermans, Jorg. 2011. "Global Governance: Parsimony and the Strictures of Complexity.” European Review 19(1), 19-29.

Marks, Gary, Liesbet Hooghe, and Kermit Blank. 1996. "European Integration from the 1980s: State-Centric v. Multi-level Governance.” Journal of Common Market Studies 34(3), 341-378.

McCulloch, Warren S. 1945. "A Heterarchy of Values Determined by the Topology of Nervous Nets." Bulletin of Mathematical Biophysics 7(2), 89-93. . 1965. Embodiments of Mind. Cambridge: M.I.T. Press.

Mearsheimer, John J. 1994/95. "The False Promise of International Institutions." International Security 19(3), 5-49. . 1995. "A Realist Reply." International Security 20(1), 82-93.

Mitrany, David. 1933. The Progress of International Government. New Haven: Yale University Press.

Murphy, Craig N. 1994. International Organization and Industrial Change: Global Governance since 185o. Cambridge: Polity Press.

Murphy, Craig N. and JoAnne Yates, eds. 2009. The International Organization for Standardization (ISO): Global Governance Through Voluntary Consensus. Milton Park, Abingdon: Routledge.

Padgen, Anthony. 1998. "The Genesis of 'Goverannce' and Enlightenment Conceptions of the Cosmopolitan World Order." International Social Science Journal 50(155), 7-15.

Reinalda, Bob. 2009. Routledge History of International Organizations: From 1815 to the Present Day. Milton Park Abingdon: Routledge.

Rhodes, R. A. W. 1996. "The New Governance: Governing Without Government." Political Studies 44(4), 652-667.

Rosenau, James N. 1997. Along the Domestic-Foreign Frontier: Exploring Governance in a Turbulent World. Cambridge: Cambridge University Press. . 2005a. "Illusions of Power and Empire." History and Theory 44(4), 7387.

. 2005b. "Global Governance as Disaggregated Complexity.” In Alice D. Ba and Matthew J. Hoffmann eds., Contending Perspectives on Global 
Governance: Coherence, Contestation, and World Order, Milton Park Abingdon: Routledge, 131-153.

Rosenau, James N. and Ernst-Otto Czempiel, eds. 1992. Governance Without Government: Order and Change in World Politics. Cambridge: Cambridge University Press.

Sadurski, Wojciech. 2014. Rights Before Courts: A Study of Constitutional Courts in Postcommunist States of Central and Eastern Europe. 2nd ed. Dordrecht: Springer.

Schakel, Arjan H., Liesbet Hooghe, and Gary Marks. 2015. "Multilevel Governance and the State.” In Stefan Leibfried, Eevelyn Huber, Matthew Lange, Jonah D. Levy, Frank Nullmeier and John D. Stephens eds., The Oxford Handbook of Transformations of the State, Oxford: Oxford University Press, 269-285.

Schwarzenberger, Georg. 1951. Power Politics: A Study of International Society. 2nd ed. London/New York: Stevens/F. A. Praeger.

Sell, Susan K. 2003. Private Power, Public Law: The Globalization of Intellectual Property Rights. Cambridge: Cambridge University Press.

Shils, Edward. 1961. "Centre and Periphery." In Paul Ignotus, Michael Polanyi, et al. eds., The Logic of Personal Knowledge: Essays Presented to Michael Polanyi, Glencoe: The Free Press, 117-130.

. 1975. Center and Periphery: Essays in Macrosociology. Chicago: University of Chicago Press.

Smouts, Marie-Claude. 1998. "The Proper Use of Governance in International Relations." International Social Science Journal 50(155), 81-89.

Stahn, Carsten, ed. 2015. The Law and Practice of the International Criminal Court. Oxford: Oxford University Press.

Stark, David. 1999. "Heterarchy: Distributing Authority and Organizing Diversity.” In John Heny III Clippinger ed., The Biology of Business: Decoding the Natural Laws of Enterprise, San Francisco: Jossey-Bass Publishers, 153-180.

Stone Sweet, Alec. 2012. "A Cosmopolitan Legal Order: Constitutional Pluralism and Rights Adjudication in Europe." Global Constitutionalism 1(1), 53-90.

Stone Sweet, Alec and Kathleen Stranz. 2012. "Rights Adjudication and Constitutional Pluralism in Germany and Europe.” Journal of European Public Policy 19(1), 91-107.

Supreme Court of the United States. 2015. "2015 Year-End Report on the Federal Judiciary." Accessed at http://www.supremecourt.gov/publicinfo/yearend/2015year-endreport.pdf (March 14, 2016).

Wall, Ronald and Bert van der Knaap. 2012. "Centrality, Hierarchy, and 
Heterarchy of Worldwide Corporate Networks.” In Ben Derudder, Michael Hoyler, Peter J. Taylore and Frank Witlox eds., International Handbook of Globalization and Cities, Cheltenham: Edward Elgar, 209229.

Waltz, Kenneth N. 1979. Theory of International Politics. New York: Random House.

Weber, Eugen. 1976. Peasants into Frenchmen: The Modernization of Rural France, 1870-1914. Stanford: Stanford University Press.

Weiss, Thomas G. 2000. "Governance, Good Governance and Global Governance: Conceptual and Actual Challenges." Third World Quarterly 21(5), 795814 . . 2013. Global Governance: Why? What? Whither? Cambridge: Polity.

Wolfers, Arnold. 1962. Discord and Collaboration: Essays on International Politics. Baltimore: Johns Hopkins Press.

Young, Oran R. 1999. Governance in World Affairs. Ithaca: Cornell University Press.

Zielonka, Jan. 2006. Europe as Empire: The Nature of the Enlarged European Union. Oxford: Oxford University Press. 